\title{
Women Environmental Cadres: An Assessment of Ecofeminism in Women's Environmental Movement (Case Study in Activities of "Fostering Family Welfare"or PKK in Malang, 2018)
}

\author{
Irza Khurun'in ${ }^{1}$, Tia Subekti ${ }^{2}$ \\ $\frac{\left.\text { \{irza.khurunin07@ub.ac.id }{ }^{1}\right\}}{\text { Universitas Brawijaya }{ }^{1,2}}$
}

\begin{abstract}
Ecofeminism is present to bridge the study between ecology and feminism. He tried to connect the relationship between natural damage and the dominance of masculinity. Shiva and Mies strongly depicted women as natural caretakers of the environment in which it perpetuates traditional views on the gendered division of labor. This paper critically examines the ways in which women interpret their roles and relationships related to nature by using specific case study of women environmental cadres through PKK (Fostering Family Welfare) in Malang. This article argues that the women involvement in environmental conservation through PKK is not their acknowledgement of their distinct relationship to their natural environment. Instead, it was the product of hegemony of knowledge and power by government and environmental activists. It shows that ecofeminism ignores political aspects in which actually puts the burden of environmental damage on women with portraying women as "natural" agents that take charge of environmental conservation.
\end{abstract}

Keywords: Ecofeminism, environmental conservation, women, Fostering Family Welfare

\section{Introduction}

International Ecofeminism was present in the 1970s to answer the challenges of feminist ecology. In the same year, Francoise D'Eaubanne brought the feminist ecology movement into a study of concepts called ecofeminists [1], [2]. Furthermore, Shiva and Mies studied ecofeminism as a new approach to questioning women's problems.

Ecofeminist bring the main idea that women have a natural attachment to nature, so that there is a mother earth. Secondly, ecofeminists consider environmental damage that is currently happening due to male domination of women, including male domination of nature. The existence of such domination makes the environment exploited massively. Meanwhile, women are affected by environmental damage.

Starting from this assumption, ecofeminism proposes solutions by eliminating male domination of women and nature. The second, bringing women actively involved in environmental conservation. However, what happened was, instead of giving public space to women, it actually increased the burden on women. 
The first burden, women must be responsible for domestic affairs in the household. Secondly, women are required to be responsible for environmental conservation.

Instead of reducing the dominance of patriarchal values, in some cases it actually perpetuates this dominance. Researchers took the case of women's involvement as environmental cadres in environmental conservation in Malang City. Malang has one working program or policy namely environmental conservation through PKK or Fostering Family Welfare. In this article the author will present a critique of eco-physical logic that excludes political aspects and the vulnerability of power and knowledge hegemony.

\subsection{Woman Environmental Movements: A Case Study In Malang}

a. Environmental issues in Malang

Environmental issue is one of the focuses of the Malang government. Malang is currently facing various challenges related to the environment. As a city of education, thousands of new students from out of town arrived in Malang. It cause congestion, air pollution, increase in air temperature, waste problem, and another environmental problem. The Environmental Agency said that the temperature of Malang had increased quite dramatically over the past 10 years. They said that it was caused by increased carbon emissions. The table below shows the increase of air temperature in Malang.

Table 1. The Increase of Air Temparature in Malang

\begin{tabular}{lll}
\hline No. & Year & Air Temperature \\
\hline 1. & 1997 & $23,4^{\circ}$ celcius \\
2. & 2006 & $24,2^{\circ}$ celcius \\
3. & 2007 & $33^{\circ}$ celcius \\
4. & 2008 & $34^{\circ}$ celcius \\
5. & 2015 & $35^{\circ}$ celcius \\
\hline & & Source: processed by researchers, 2018
\end{tabular}

Various policies have been issued by the government to address environmental problems, such as increasing the amount of urban forest and Open Green Space (RTH), waste management, and environmental conservation through environmental cadres in each subdistrict. Environmental cadres had made in the Neighborhood level, lowest level of local government, particularly PKK. It means that women in villages or kampong have responsibility to conserve the environment.

\subsection{PKK as a Women's Environmental Movement in Malang}

PKK is women organization that came up in 1957 when there was a Home Economic Seminar [3], [4]. Then, in 1967 it became legally binding guided by the government. The beginning of the establishment of PKK was aimed at accommodating the wives of Functionary. It was initiated by Isriati Moenadi, the wife of Governor of Central Java at that time. Then, she socialized the PKK into society, particularly women, although they were not the wives of Functionary. This was driven by the incidence of starvation which afflicted several regions of Indonesia at that time. Until now PKK activities are still actively carried out by groups of women in the community. The legal basis of the PKK currently refers to the Regulation of the Minister of Home Affairs of the Republic of Indonesia Number 1 of 2013 concerning Community Empowerment through the Family Empowerment and Welfare Movement.

PKK aims to improve family welfare. It has 10 main program, namely: 1)Understanding and practicing Pancasila; 2)Mutual cooperation (Gotong Royong); 3)Availability of food; 4)Availability of Clothes; 5)Housing and household management; 6)Education and skills; 
7)Health; 8)Livelihood through cooperatives; 9)Environmental sustainability; and 10)Healthy planning. Meanwhile the institutional structure of the PKK is arranged starting from the central level with the general chairperson of the wife of the Minister of Home Affairs to the management up to the Neighborhood level. Meanwhile, the wife of the Minister of Home Affairs acts as the head of the National PKK. The institutional structure is structured to the lowest level of government, namely the Neighborhood level, chaired by the wife of the head of Neighborhood.

In the Neighborhood level, PKK contains of four Working Group (called Kelompok Kerja or Pokja). Through the working group that has been formed, housewives can go down and participate actively in their environment. The following are the tasks and functions of each Working Group of PKK in the Neighborhood level.

Table 2 The Increase of Air Temperature in Malang

\begin{tabular}{lll}
\hline No. & Working Group & Task and Function \\
\hline 1. & Working Group I & Religion \\
2. & Working Group II & Skills \\
3. & Working Group III & Environment \\
4. & Working Group IV & Healthy \\
\hline Source: & Interview with the Chairperson of RT 8 RW 9, Merjosari, Malang, in June 2018
\end{tabular}

PKK groups have a role in environmental conservation even though they are not dominant. Environmental conservation activities carried out by the PKK are a simple form of conservation activity. The limitation in skill and time are the main reasons for choosing the simplest form of conservation. Furthermore, PKK members are women, which until now in Indonesia, they have a big responsibility in household or domestic affairs. Moreover, for urban women, working to earn a living is important to support the family's economy. So that, the choice of simple activities will not burden them.

Through Working Group IV women who are members of the PKK in each Neighborhood in Malang compile several agendas related to environmental conservation. There are at least five activities carried out by PKK. First, plants family medicines (toga). This activity is an effort to restore the tradition of using traditional medicine and minimizing the use of chemical drugs in healing simple diseases in families. These plants include turmeric, guava, katuk leaves, ginger, lime, etc. This type of plant is used as first aid to some diseases such as abdominal pain, cough, fever, diarrhea, or colds.

Second is cleaning the environment regularly. Environmental health begins with environmental hygiene. Routine environmental cleaning activities are usually carried out every week or 2 weeks. Activities are carried out by sweeping or cleaning dirty garbage to reduce the breeding of larvae carrying disease.

Thirdly, waste management. Waste management in Neighborhoods is also handled by PKK. PKK organizes daily garbage collection by imposing citizens' fees to pay for garbage workers. Contributions are charged to each family head in the amount of Rp. 25,000. Waste management are also carried out by PKK.

Meanwhile, waste management is carried out by housewives who are members of the PKK. In RT 8 RW 9 Merjosari Village, housewives PKK members manage waste by collecting plastic waste to be managed by the garbage bank in their RT. Garbage banks are managed by mosque youth in the local environment. Later, the proceeds from the sale of plastic waste will be used for mosque activities. Whereas in RT 4 RW 14 mojolangu village, PKK, accompanied by the NGO Social Humanitarian Community (KSK), utilizing plastic waste into household items. KSK has a "Trash to Creation" program, which collaborates with 
the PKK to utilize plastic waste. The following are examples of processed household waste that has been made.

Figure 1. Plastic Waste Recycling by PKK in Mojolangu

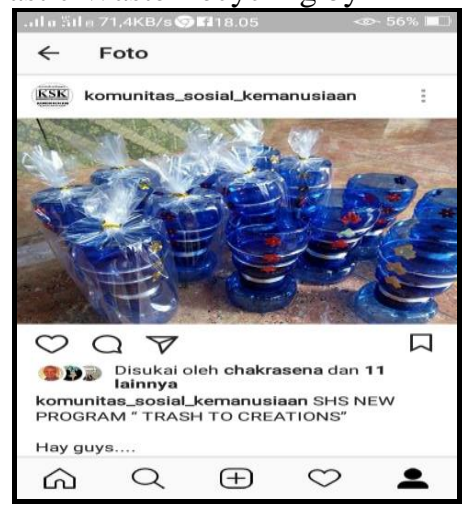

Source: documentation by Siana, KSK Coordinator, 2018

\section{Result and Discussion}

PKK not only manages plastic waste but also organic waste. PKK not only manages waste plastic but also organic waste. PKK in Merjosari in April 2018 conducted training on making jam from dragon fruit skin. This is due to the high consumption of dragon fruit and the presence of nutrients in the skin for dragons.

Fourth is utilization of the yard. Utilization of the yard is done by encouraging housewives to plant crops that are beneficial to family needs, such as, planting fruit, vegetables and spices. At RT 8, PKK often purchases seeds together, then is managed by the head of the RT. For example guava, strawberry, lettuce, mustard greens, and other types of vegetables. Planting fruits and vegetables is done using polybag.

Fifth is no smoking area. PKK RT 8 RW 9 Merjosari Village initiated the movement to ban smoking inside the house. PKK calls on all housewives to prohibit their husbands from smoking inside the house. They put cigarette ashtrays outside the house and put up smoking bans posters around the neighborhood. It aims to maintain the health of the air in the house.

Women's environmental movement through PKK cannot be separated from the encouragement of the government, academics, and NGOs. Various efforts have been made to stimulate the participation of housewives to join actively in the PKK. They are, first is often getting assistance from NGOs, academics from various universities and students in the city of Malang. Second, the environmental hygiene competition held by the city government encourages PKK to be active in the cleanliness of its environment. Third, there is the guidance and supervision of PKK at the national level.

\subsection{Study Of Ecofeminism In Women's Environmental Movement}

2.1.1 Women Movements in Indonesia, A Short Analysis

Before entering the discussion about the PKK further we should keep in mind about the history of the women's movement in Indonesia. The women's movement in Indonesia has a long history in the tide on struggle for women's rights. The women's movement was initially focused on the struggle for women's basic rights, such as obtaining education or gaining space 
in the realm of government politics. Now, in the post-reform era, the women's movement widened their movement into the realm of environmental struggle. This paper is present to provide an overview at one blow critique of ecofeminism towards women's environmental movement in Indonesia by taking case studies in Malang.

The women's movement grew in Indonesia in the early 20th century, since then studies on feminism have entered and spread in the scope of people's lives. It is marked with the establishment of modern schools by Dutch colonial government through Dutch "ethical" policies with the opening of modern schools for women, as well as modern organizations by Kaoem Boemipoetra. Hereafter, the ideas of feminism and gender (in) equality inspired many people, especially women. Indonesia has female figures in the era of colonialism, say Cut Nyak Dien and Cut Mutia, commander of the Aceh war; Ratu Sima, a female leader in Central Java; and R.A Kartini with the idea of feminism that rejects male domination over women.

The period of resistance to colonialism in Indonesia was inseparable from the women's movements, one of them was a female activist Siti Soendari who had the opportunity to speak at the event, which became a milestone for the youth, Soempah Pemuda in 1928. Women's struggle continued with the holding of the Women's Congress in Desember 22nd-25th 1928.

Ride into independence era (post-colonialism) in 1945-1966, there was PERWARI (Persatuan Wanita Republik Indonesia or Women's Association of Republic of Indonesia). They were focused in home front activities such as kitchen affairs and help PMI (Indonesian Red Cross), yet then they also focused in education. PERWARI was followed by GERWANI (Gerakan Wanita Indonesia or Indonesian Women's Movement) which was active in 1950's up to 1960s. GERWANI was one of the women's movements which was very active in fighting for women's rights in the political and social spectrum at that time.

Entering the New Order Era, the women's movement in Indonesia was 'turned off' by the government. GERWANI was forcibly closed because it was considered a deviant organization. Instead, the government formed women's organizations under its control such as Dharma Wanita which contained the wives of civil servants, and Dharma Pertiwi for ABRI's wives. The government internalized the values in the organization, namely the obligation of women to work on domestic or household affairs. In Javanese terms, women's affairs are $3 \mathrm{M}$ (Masak, Macak, Manak or cooking, primping, and bearing), "Manut in Pandum" or accept all gifts which means gifts from God and from husbands, "Konco Wingking" or friend behind which means woman is behind the man. In the reform and post-reform era, women's movement began to rise again. Women's movements emerged in various fields, from the economic, political, social, literary, educational, and environmental fields.

The rise of women's movement did not spontaneously make the women's movement a la government of new order era disappear. Dharma Wanita and PKK (Pembinaan Kesejahteraan Keluarga or Fostering Family Welfare), next it will be called PKK, that emerged in the New Order era were perpetuated by the government until now. Those organizations are failed products from the government of the New Order era that is still used today. Its leave the idea of equality. This reflects that the government perpetuates male domination towards women and masculinity towards femininity.

A reflection of the dominance of masculinity over femininity can be captured from the environmental movement in Malang City. One of the environmental movements in Malang City is through the PKK Main Program. Women are made into environmental cadres who aim for environmental conservation through 'empowering women'. This proposition of 'women's empowerment' seems to provide space for women, but actually only pseudo space is obtained by women. Again, women are made as objects not subjects. 


\subsection{Ecofeminism: an alternative study relating Women and Environment}

Modern feminism assumes that individuals are autonomous beings who are free from environmental influences, so ecofemists are present to connect the interrelations of individuals with the environment. Damage and destruction of the earth in the view of ecofeminism is closely related to domination of nature and domination of women. Rosemary Radford Ruether, for example, said that women should interpret that there would be no ecological solutions and solutions if the relational model was in the form of domination.

Vandana Shiva and Maria Mies in their book titled ecofeminism have made a strong case for women's role in environmental protection. They named it as ecofeminism. Ecofeminism came up in 1970-s by Francoise D'Eaubanne, then it has been the subject of sociological critique.

The environmental crisis is no longer a new thing for the community or the government. The current environmental crisis is rooted in human behavior errors. The environmental crisis, according to Arne Naess, can be overcome by fundamentally changing human perspectives and behaviour in seeing the environment and environmental management.

Ecofeminism exists as an alternative to environmental ethics that wants to sue and break the dominant viewpoint that prevails in modern society and at the same time offers new perspectives and behaviours to overcome the current environmental crisis [5].

The ecofeminist discussion is divided into two, the first to break the logic of domination which is the main cause of the ecological crisis related to gender relations. Secondly, it will discuss the alternative ethics of concern that is prioritized by ecofeminists.

The environmental crisis, according to the ecofeminist's point of view, is the existence of an anthropocentric, androsentric, and ecocentric perspective. For ecofeminism, the ecological crisis is not only caused by anthropocentric perspectives and behaviour, but also by androcentric and ecocentric [5]. In these three points of view, the dominance of humans (nonnature) over non-humans (nature) is prioritized. Domination logic according to Karren J. Warren is a structure and way of thinking that tends to justify domination and subordination [5].

Ecofeminism believes that social and political structures and institutions must be radically changed to eliminate or at least reduce human domination, oppression and exploitation of nature [5].

\subsection{Ciritque Ecofeminism towards Women's Environmental Movement through PKK}

The involvement of women in environmental management is important because women are the party affected by the problem of environmental damage. Women and the environment are closely related. The position of women with the environment can be seen from two different sides. First, women as victims. Second, women as environmental conservation agents.

The link between women and the environment encourages the emergence of ecofeminism or ecological feminism. This thinking emerged one of them was backed up by the fact that women became parties who were severely affected by environmental damage. The patriarchal culture is considered to have damaged the earth's resources without regard to the long-term impacts. In the view of ecofeminism, the protection of different forms of life on earth and the culture of human society is a prerequisite for sustaining life on this planet. Andit Enri Anpa in his research entitled "The Impact of Environmental Damage on Women and Children" shows the results that there is a link between environmental damage to the fate of women. He saw that environmental damage has a direct impact on poverty which in turn leads to crime in women in the form of trafficking. Furthermore, the case of forest fires in Riau in 2016 also 
shows the fact that women are the most affected by the problem. The increase in palm oil production results in an increase in the use of pesticides which are based on pollution in the river flow. Meanwhile, as a housewife, women's daily activities depend on the river and the availability of clean water.

Aside from being a victim, in other cases women have great potential in environmental conservation efforts. Today, various studies, especially in Indonesia, have shown that women have important positions in environmental affairs. First, research conducted by Dian Wismar'ein et al. Entitled "Women in Water Resources Management in Rahtawu Village, Kudus Regency". Second, Yulanda Caesfa, et al entitled "Women's Perception of the Environment and Its Participation in Household Waste Management (The Case of a Village in Babakan Village, Dramaga District, Bogor Regency, West Java Province)" [2]. Third, Nur Fadhilah et al entitled "Women and Environmental Conservation: A Study of Diamond Waste Bank Malang East Java" [6].

Criticism of ecofeminism the first is that the majority of PKK activities are in private spaces, and few are in public spaces. Second, the dominance of the power owners and knowledge owners forces the company to be involved in the public space or the PKK. That is, the PKK is a practical action born of coercion rather than awareness. Third, the PKK Basic Program actually puts women back in the domestic activities. The linking of women with the environment does not make masculine domination lessened.

The proof, exploitation of nature continues. Greening activities, waste segregation, and toga planting are not the core of the women's movement in the environmental field according to ecofeminism. The essence of ecofeminism is to minimize or eliminate the dominance of one thing against another. Human dominance over nature (anthropocentric), male domination of women, economic domination over the environment (ecocentric), and the dominance of masculinity over femininity are the existence evidence in reality that shows that in the women's movement, women do not move on the basis of their ideas and feelings but on the basis of the encouragement of the local government and NGOs. That is, the hegemony of power and knowledge applies in shaping one's behavior as presented by Antonio Gramsci.

\section{Conclusion}

The conclusion of this article is the women involvement in environmental conservation through PKK is not their acknowledgement of their distinct relationship to their natural environment. Instead, it was the product of hegemony of knowledge and power by government and environmental activists. It shows that ecofeminism ignores political aspects in which actually puts the burden of environmental damage on women with portraying women as "natural" agents that take charge of environmental conservation.

\section{References}

[1] F. D’Eaubonne, Éros minoritaire. Paris: Balland, 1970.

[2] J.-L. Gautero, "Françoise d'Eaubonne, éco-féminisme et anarchie," Mod. Contemp. Fr., vol. 24, no. 2, pp. 179-191, 2016.

[3] S. E. Wieringa, "Two Indonesian women's organizations: Gerwani and the PKK," Bull. Concern. Asian Sch., vol. 25, no. 2, pp. 17-30, 1993.

[4] S. Wieringa, "Ibu or the beast: gender interests in two Indonesian women's organizations," Fem. Rev., vol. 41, no. 1, pp. 98-113, 1992. 
[5] A. Keraf, Etika Lingkungan Hidup. Jakarta: Kompas, 2010.

[6] N. Fadhilah and N. M. Naharin, "Perempuan Dan Konservasi Lingkungan: Studi Bank Sampah Berlian Malang JawaTimur,” Al-Tahrir J. Pemikir. Islam, vol. 17, no. 2, pp. 269-288, 2017. 